\title{
CHARYZMAT, DUCHOWOŚĆ I POSŁANNICTWO BRATA ZAKONNEGO NA PRZYKŁADZIE ZGROMADZENIA MISJONARZY ŚWIĘTEJ RODZINY
}

DOI: http://dx.doi.org/10.12775/TiCz.2019.048

Streszczenie. Brat zakonny ma udział w misterium zbawczym Chrystusa i Kościoła. Potwierdza, że misja Kościoła, z poszanowaniem różnych powołań jest jedna dla wszystkich ${ }^{1}$. Staje się przewodnikiem życia duchowego. Do zasadniczych elementów jego posłannictwa należy: tworzenie wspólnoty oraz przyjęcie stylu życia Jezusa. Pomaga w tym dobrze prowadzona formacja początkowa i ciągła. Dokumenty Zgromadzenia poświęcają jej wiele miejsca, dokładnie precyzując poszczególne wymogi wobec kandydatów i formatorów.

Słowa klucze: brat zakonny; charyzmat; duchowość; posłannictwo.

* Dr hab. Adam Józef Sobczyk - kapłan ze Zgromadzenia Misjonarzy Świętej Rodziny. Od 2007 roku członek Międzynarodowej Komisji Formacyjnej Zgromadzenia Misjonarzy Świętej Rodziny, od 2009 roku członek korespondent Polskiego Stowarzyszenia Teologów Duchowości. Wykładowca teologii duchowości, kierownictwa duchowego i poradnictwa rodzin; rekolekcjonista. Zainteresowania naukowe obejmują głównie zagadnienia historii i teologii duchowości ze szczególnym uwzględnieniem duchowości zakonnej oraz duchowości małżeńskiej i rodzinnej.

${ }^{1}$ Zob. Tożsamość i misja, nr 1. 
Abstract. The carism, spirituality end mission of friar, for example of Congregation of the Missionary of the Holy Family. The Friar has a part in the salutary mystery of the Christ and the Church. He confirms that the Church's mission, with the respecting of different vocations, is one for everyone. He becomes a guide of the spiritual life. The essential elements of his mission are: creating a community and accepting the lifestyle of Jesus. A well-run initial and continuous formation helps in this. The documents of the Assembly devoting a lot of space to it, precisely specifying individual requirements for candidates and formators.

Key words: Friar; charism; spirituality; mission.

Termin Bracia (gr. Adelfoi; łac. Fratres), w kościele pierwotnym oznaczał członków wspólnoty chrześcijańskiej dla zaznaczenia ich jedności w Chrystusie (por. 1 Kor 5, 11). To nazwa osób należących do niektórych zakonów, powstała w XIII wieku, wraz z formowaniem się zakonów żebrzących. Bracia zakonni starali się żyć Ewangelią i być braćmi ludzi, wśród których żyli. Nazwę bracia stosuje się także w odniesieniu do zakonników nieprzyjmujących święceń, członków wspólnot laickich (np. Bonifratrzy), członków niektórych wspólnot istniejących od średniowiecza niezależnie od kategorii członków (np. Bracia mniejsi - Franciszkanie), a także członkowie heterodoksyjnych wspólnot średniowiecznych (np. Bracia Czescy). Statystyki podają, ze bracia albo zakonnicy świeccy stanowią dziś jedną piątą wszystkich zakonników w Kościele ${ }^{2}$.

Określenie brat zostało nadane niektórym zakonnikom w Kościele już u samych początków życia konsekrowanego. Wskazuje ono jego miejsce w przestrzeni wspólnoty kościelnej, w której przypomina: „ wszyscy jesteście braćmi” (Mt 23, 8)³. Ponadto podkreśla wspólną godność, rów-

2 Zob. J. Duchniewski, Bracia, Encyklopedia katolicka, t. II, red. F. Gryglewicz i inni, Lublin 1995, kol. 991; M. Daniluk, Encyklopedia Instytutów życia konsekrowanego i Stowarzyszeń życia apostolskiego, Lublin 2000, s. 57; Kongregacja Instytutów Życia konsekrowanego i Stowarzyszeń życia apostolskiego, Tożsamość i misja brata zakonnego w Kościele (dalej Tożsamość i misja), Warszawa 2016, nr 2.

${ }^{3}$ Zob. Jan Paweł II, Adhortacja apostolska, Vita consecrata z 25.03 .1996 (dalej VC), nr 60. 
ność i podobieństwo wszystkich wierzących (por. Mt 5, 45), powołanych do kształtowania powszechnego braterstwa w Chrystusie (por. Rz 8, 29) ${ }^{4}$.

Bibliografia $\mathrm{w}$ tym temacie, nie jest zbyt bogata. Teksty posoborowe omawiają głównie zagadnienie formacji braci zakonnych ${ }^{5}$. Najwięcej miejsca analizie tożsamości brata zakonnego poświęciła Kongregacja do spraw Instytutów Życia Konsekrowanego i Stowarzyszeń życia apostolskiego w dokumencie pt.: Tożsamość i życie brata zakonnego w Kościele (2015). Pismo to wraz dokumentami Zgromadzenia Misjonarzy Świętej Rodziny stanowić będzie przedmiot formalny naszych analiz badawczych. Konstytucje tegoż Zgromadzenia z roku 1985 w numerze pierwszym podają, że: „jesteśmy apostolsko-klerycką wspólnotą zakonną na prawie papieskim"'. W naszym przypadku chodzić będzie zatem o brata zakonnego realizującego swoje powołanie w Instytucie kleryckim.

\section{CHARYZMAT BRATA ZAKONNEGO}

Genezy życia brackiego w formie niezinstytucjonalizowanej należy szukać już w pierwotnym Kościele. Na kartach Dziejów Apostolskich został ono przedstawione jako wspólnota uczniów. Członków rodzącego się Kościoła można nazywać braćmi z racji powołania ich przez Mistrza z Nazaretu. Zadaniem braci jest głoszenie Ewangelii słowem i czynem. Ich misja opiera się na Eucharystii i przepowiadaniu. W realizacji misji doskonale wpisuje się charyzmat brata. Wraz z szczególnym powołaniem brat otrzymuje od Boga określony dar, by nim służyć Kościołowi i poszczególnym ludziom. W przypadku brata zakonnego, chodzić będzie o służbę całemu Ludowi Bożemu, prowadzoną integralnie i w sposób prorocki, poprzez specyficzny wkład życia konsekrowanego ${ }^{7}$.

${ }^{4}$ Zob. Tożsamość i misja, nr 1.

5 Zob. Kongregacja zakonów i Instytutów świeckich Essential elements z 31.05.1983 (dalej EE), nr 35; Kongregacja zakonów i instytutów świeckich oraz kongregacja Biskupów, Wytyczne dla wzajemnych stosunków między Biskupami i Zakonnikami w Kościele, Mutue relationes z 14.05.1978 (dalej MR), nr 29; Kodeks Prawa kanonicznego, 1983 (dalej KPK), kan 659-660.

${ }^{6}$ Zgromadzenie MSF, Konstytucje 1985, nr 1, KPK $588 \S 2$.

7 Zob. VC 33; Tożsamość i misja, nr 8. 
Charyzmat brata zakonnego przez długi czas nie znajdował się w optyce zainteresowań teologiczno-duchowych. Zajmował miejsce drugorzędne w stosunku do funkcji prezbiterialnych. Jednak w historii Kościoła pojawi się nurt, w którym coraz więcej założycieli różnego rodzaju instytutów religijnych, doceniało także laicki charakter ich fundacji. W ten sposób przywrócono braciom właściwe im miejsce w życiu konsekrowanym. Znakomitym przykładem są tutaj bracia św. Benedykta, którzy byli ewangelizatorami Europy, czy też Bracia Mniejsi św. Franciszka, którzy zrodzili się jako zakon mieszany, złożony ze świeckich i kapłanów. W wieku XVI i XVII fundatorzy zgromadzeń zakonnych odnowili projekt laickiego życia zakonnego, realizując je we wspólnotach, które nadają szczególne znaczenie relacjom braterskim między ich członkami. Zaakcentowali pewną korelację pomiędzy powołaniem brata zakonnego a aktualnymi potrzebami społecznymi. W ten sposób wyznaczyli braciom specyficzne cele, polegające na odkryciu przestrzeni, w której mogliby swoim powołaniem odpowiedzieć na potrzeby ludzi ${ }^{8}$.

Charyzmaty założycielskie, które zrodziły się wraz z powstawaniem Zakonów i Zgromadzeń zakonnych, nierzadko dzisiaj przekraczają widzialne struktury Kościoła. Osoby świeckie, zakonnicy, zakonnice i kapłani łączą się w jedną rodzinę, aby razem żyć charyzmatem, który dał jej początek. Realizują w ten sposób ewangeliczne oblicze, które ten charyzmat objawia, i wpisują się w ogólną misję Kościoła9

Źródłem charyzmatu braci jest Duchu Święty. To On w dniu Pięćdziesiątnicy zstąpił na braci zgromadzonych na modlitwie i posłał ich, aby dawali świadectwo (por. Dz 2, 1nn). Analizując charyzmat brata zakonnego, widać wyraźnie, że samo braterstwo i misja brata wzajemnie się przenikają. Pielęgnowanie braterstwa rodzi większą świadomość misji, a realizowanie misji rodzi braterstwo. W tym realizuje się zarówno charyzmat, jak i tożsamość brata zakonnego.

8 Święty Jan Boży i święty Jan Chrzciciel de la Salle, tak jak i święta Aniela Merici, między innymi, byli narzędziami Ducha, aby wprowadzić do Kościoła nowe charyzmaty fundacyjne, które bardzo licznie będą powstawać zwłaszcza w wieku XIX. Zob. Tożsamość i misja, nr 9.

9 Zob. Kongregacja do spraw Instytutów Życia Konsekrowanego i Stowarzyszeń Życia Apostolskiego. Instrukcja: Rozpoczać na nowo od Chrystusa, (dalej RCH), Poznań 2002, nr 31; Tożsamość i misja, nr 38. 
Samo określenie „bracia” wskazuje na to, co zakonnicy traktują jako fundamentalną misję swego życia. Ukazuje, zdaniem św. Jana Pawła II, specyficzny charyzmat powołania brackiego w Kościele. Jego zdaniem:

Zakonnicy ci są powołani, aby być braćmi Chrystusa, głęboko zjednoczonymi z Nim - „pierworodnym między wielu braćmi” (Rz 8, 29); aby być braćmi jedni drugich, we wzajemnej miłości i we wspólnej służbie dobru Kościoła; braćmi każdego człowieka poprzez świadectwo miłości Chrystusa wobec wszystkich, zwłaszcza najmniejszych i najbardziej potrzebujących; braćmi budującymi powszechne braterstwo Kościoła ${ }^{10}$.

W ten sposób powołanie brata stanowi rodzaj odpowiedzi Boga na brak braterstwa w świecie. U korzeni powołania brata tkwi głębokie doświadczenie solidarności. Urzeczywistnia się ono w głębokiej wrażliwości na wszystko, co narusza godność najmniejszych z ludu, uciśnionych, pozostawionych na marginesie oraz tych, do których Ewangelia jeszcze nie dotarła. Brat zakonny przeżywa swój specyficzny charyzmat w kontekście komunii przez przynależność do Ludu Bożego. Włącza się w misję Kościoła i dzieli ją z innymi wiernymi ${ }^{11}$.

W realizacji charyzmatu brata zakonnego pomaga aktualny kontekst Kościoła-Komunii. Umożliwia on świadczenie miłości braterskiej, nie tylko wewnątrz swoich wspólnot, lecz także wobec całej wspólnoty kościelnej. Bracia stają się przewodnikami życia duchowego dla siebie nawzajem i dla osób świeckich. Po bratersku towarzyszą innym i pomagają im odkryć bogactwo chrześcijańskiego dziedzictwa. Czynią to m.in. poprzez: życie sakramentalne, przynależność do Ludu Bożego, osobistą integrację laickości i sakralności, znak obecności Boga w realiach świeckich, życie braterskie we wspólnocie, charyzmat dzielony z innymi ${ }^{12}$.

We wspólnocie Kościoła brat zakonny znajduje sens własnego powołania. Jan Paweł II, a za nim późniejsze dokumenty Kościoła, wzorują charyzmat brata zakonnego na postaci Sługi Jahwe, opisanego przez

10 Zob. VC 60.

11 Tamże, 41.46 .

${ }_{12}$ Tamże, 55; Sobór Watykański II. Konstytucja duszpasterska o Kościele w świecie współczesnym. Gaudium et spes (dalej KDK), 1965, nr 1; RCH 31; Jan Paweł II, Adhortacja apostolska. Christifideles laici z 30.12.1988, (dalej CHL), nr 24; Tożsamość i misja, 10. 
Izajasza, do którego Bóg mówi: „ustanowiłem cię przymierzem dla ludzi” (Iz 42, 6). Jezus uosabiający postać Sługi Jahwe wzywa tych, którzy w Niego wierzą, by kontynuowali pośrednictwo powierzone Słudze: bycie przymierzem dla ludzi. Tutaj wyłania się w sposób naturalny charyzmat brata zakonnego do bycia pośrednikiem w wymiarze zarówno osobistym, jak i wspólnotowym. Brat zakonny odczytuje w nim powołanie do bycia pamiątką przymierza na mocy swej własnej konsekracji dla Boga w życiu braterskim i we wspólnocie dla misji ${ }^{13}$.

Charyzmatem brata w Kościele jest świadczenie wobec ludzi o potrzebie wierności wartościom i dążenie do świętości we współczesnym świecie $^{14}$. W takiej postawie znajdują swój wyraz wszystkie inne rodzaje służby i posługi, jakie pełnią bracia zakonni. Z kolei samo braterstwo braci zakonnych jest impulsem dla całego Kościoła, aby, w obliczu pokusy dominowania, poszukiwania pierwszego miejsca, traktowania władzy jako potęgi, uobecniać ewangeliczną wartość relacji braterskich, horyzontalnych (Mt 23, 8-10). Charyzmatem brata jest doświadczenie miłości Boga (por. $1 \mathrm{~J} 4,16$ ), które umożliwia kształtowanie własnej tożsamości i służbę ludziom, do których inni nie docierają. Potwierdzają to słowa Założyciela, ks. Jana Berthier, skierowane do swoich uczniów: „idźcie do tych, których z oddali wezwie Pan"15.

Takie rozumienie charyzmatu brata zakonnego prowadzi do wzrostu komunii za pośrednictwem braterskiej służby. U jej podstaw leży decyzja o „darze z siebie składanym z miłości do Pana Jezusa, a w Nim - do każdego członka ludzkiej rodziny” (por. Kpł 19, 18). Powołanie brata polega na byciu świadkiem i pośrednikiem tego daru i planu komunii zakorzenionego w komunii trynitarnej. Ma na celu pomoc w odnowieniu relacji horyzontalnej między Bogiem a ludzkością, w samym wnętrzu ludzkości, gdzie Bóg zechciał zamieszkać. W ten sposób relacje Ojciecdzieci przechodzą w relacje braterstwa. Dlatego „brat” znaczy to samo co „pośrednik miłości Boga”, (J 3, 16), a bycie „bratem” oznacza także być pośredniczenie w miłości Syna, który „do końca ich umiłował” (J 13,

${ }_{13}$ Zob. VC 72; Tożsamość i misja, 5.

14 Zob. VC 33.

15 Zob. Tożsamość i misja, 13; J. Berthier, Constitutiones, Reims 1895, nr 1.16.18; Zgromadzenie MSF, Konstytucje 1985, nr 2. 
1) ${ }^{16}$; oraz Ducha Świętego, który poprzez sakramenty i profesję zakonną czyni nas duchową świątynią". Brat zakonny konsekruje całe stworzenie, uznając obecność Boga i działanie Ducha w stworzeniach, w kulturach i w wydarzeniach. Z kolei, szanując tę czynną obecność, może głosić ją swoim współczesnym ${ }^{17}$.

Sposobem ofiarowania siebie Bogu dla brata zakonnego jest złożenie ślubów zakonnych, poprzez które ukazuje on swoje pragnienie całkowitego upodobnienia się do Chrystusa. Przeżywa czystość jako doświadczenie miłości Boga, przez którego czuje się zmobilizowany do miłowania wszystkich; ubóstwo jako ktoś, kto otrzymał za darmo drogocenną perłę królestwa Bożego; dzięki temu jest gotów budować braterstwo i służyć, w miłości, wszystkim, zwłaszcza najuboższym. Rozumie posłuszeństwo jako wspólne poszukiwanie woli Ojca, w braterstwie ożywianym przez Ducha oraz Regule Instytutu ${ }^{18}$.

W Zgromadzeniu Misjonarzy Świętej Rodziny, na temat charyzmatu wypowiadają się Konstytucje i Dyrektorium Generalne. W troskę o misje, rodziny i powołania włączają one także braci zakonnych ${ }^{19}$. Do tych dokumentów nawiązuje Dokument programowy Prowincji polskiej MSF, który wobec malejącej ilości powołań brackich oraz wzrastającej liczbie odejść braci ze Zgromadzenia, zastanawia się nad redefinicją roli i pozycji brata zakonnego oraz jego statusu w domu zakonnym w zakresie obowiązków i przywilejów ${ }^{20}$. Dokument ten odnośnie wizji roli i miejsca brata zakonnego w Prowincji MSF decyzję pozostawia Zarządowi Prowincji. Zaznacza jednak konieczność dobrej selekcji kandydatów. Ponadto jako podstawowe zadanie uważa pogłębienie i rozwój powołania zakonnego w duchowości świętorodzinnej. Zaleca lepsze poznanie Ojca Założyciela oraz charyzmatu i posłannictwa Zgromadzenia ${ }^{21}$.

16 Zob. Tożsamość i misja, 12-13.

17 Zob. tamże, nr 14-15

18 Zob. VC 42; Tożsamość i misja, nr 17.

19 Zob. Konstytucje 1985, nr 1-4; Dyrektorium polskiej Prowincji MSF, Rzym 1985, nr 01-010.

20 Zob. Dokument programowy Polskiej Prowincji MSF, Bąblin 2002, s. 28.

${ }^{21}$ Zob. tamże, s. 29. 


\section{DUCHOWOŚĆ BRATA ZAKONNEGO}

Dokumenty Kościoła pośród wielu wymiarów duchowości brata zakonnego szczególną uwagę zwracają na aspekt Wcielenia, maryjności, wspólnotowości i komunii oraz apostolatu. Kościół ożywiany przez Ducha Świętego umacnia świadomość bycia Ludem Bożym, w którym wszyscy posiadają tę samą godność, otrzymaną na chrzcie. Każdy człowiek na swojej własnej drodze życiowej jest, w jakiś sposób, powołany do świętości i współodpowiedzialności za misję ewangelizacyjną. W ten sposób, według swego własnego powołania, charyzmatu i rodzaju służby, staje się również widzialnym znakiem dla innych ${ }^{22}$.

Brat jest wezwany do przeżywania duchowości wcielonej i jednoczącej, która otwiera go na spotkanie z Bogiem, nie tylko w słuchaniu Słowa, w sakramentach, w liturgii i w modlitwie, ale także we wszystkich swoich pracach i zadaniach. Chodzi o formę nieustannej modlitwy, którą Bracia zakonni łączą z wymiarem służebnym, cechującym ich życie konsekrowane ${ }^{23}$.

Istotnym rysem duchowości brata zakonnego jest maryjność. Opiera się ona na Ewangeliach synoptycznych przedstawiających scenę, w której Jezus ustala jasną różnicę między „swoją matką i swoimi braćmi” według ciała a „swoją matką i swoimi braćmi, którzy słuchają słowa Bożego i wypełniają je" (Łk 8, 21). Pierwsi stoją na zewnątrz domu, wołają Go z zewnątrz; drudzy stoją wokół Niego, w domu, słuchając Go. W tej nowej kategorii relacji rodzinnej, ustalonej przez Jezusa, Maryja znajduje swoją prawdziwą wielkość i swoje głębokie znaczenie dla wspólnoty chrześcijańskiej. Stanowi Ona więź jednoczącą w rodzącej się wspólnocie braci. W tym też braterstwie modlących się Matka Boska przyjmuje Ducha Świętego (por. Dz 1,14; 2, 1-4) 24. Podobnie jak Maryja, brat zakonny jest zaproszony do intensywnego przeżywania duchowości Słowa, do doświadczania przebywania w domu, wokół Jezusa, słuchania Jego przesłania i do przeżywania tajemnicy Ojca, który czyni nas braćmi

${ }_{22}$ Zob. Sobór Watykański II. Konstytucja dogmatyczna o Kościele, Lumen gentium (dalej KK) 1964. Nr 13; Tożsamość i misja, nr 6.

${ }_{23}$ Zob. Tożsamość i misja, nr 19.

${ }^{24}$ Zob. tamże, nr 20. 
między sobą i z Jezusem. To zadanie doskonale realizuje się w duchowości świętorodzinnej Zgromadzenia Misjonarzy Świętej Rodziny ${ }^{25}$.

Duchowość braci zakonnych ma swój wymiar wspólnotowy. Trynitarne misterium komunii życia wewnętrznego zamienia się w dar dzielony przez braci we wspólnocie, a następnie wykorzystywany jest w działalności apostolskiej. Podstawą wspólnoty zakonnej jest przede wszystkim dar otrzymanego braterstwa. Wspólnota braci demonstruje jego powszechny charakter, ponieważ nie opiera się na naturalnych więzach, lecz na mocy Ducha Świętego, która jest żywym początkiem miłości między ludźmi ${ }^{26}$. Potwierdzają to pierwsze Konstytucje Zgromadzenia, mówiące o wszystkich misjonarzach kapłanach i braciach zakonnych:

Niech nie zapominają, że szacunek i wzajemna miłość przewyższają wszystkie reguły oraz że Konstytucje i wszystkie śluby zakonne mają jedynie na celu umocnienie w duszach miłości ku Bogu i ku bliźniemu. Dlatego też niech się usilnie starają współzawodniczyć pomiędzy sobą we wzajemnym szacunku, stanowić jedno serce i jedną duszę, pomagać sobie wzajemnie w pracy, pocieszać się wzajemnie w życiowych trudach oraz nawzajem się budować ${ }^{27}$.

Dokumenty Kościoła podkreślają, że zasadniczą właściwością życia zakonnego braci, jest przebywanie we wspólnocie. Służy ono intensywnemu wspieraniu komunii braterskiej. Tam brat zakonny doświadcza tajemnicy Jezusa zmartwychwstałego. Wspólnota jest przestrzenią teologalną, w której Jezus uobecnia się pośród braci (por. Mt 18, 20), aby złączyć ich jednym sercem, udzielić im swojego Ducha (por. J 20, 22) i posłać, by głosili. Wspólnota braterska nie zrealizuje się jednak automatycznie tylko przez przestrzeganie zasad, które regulują życie wspólne. Stanowi ona doświadczenie czegoś więcej niż wspólne miejsce zamieszkania. Chodzi w niej o zgromadzenie się razem w celu przeżywania głębi bycia razem i stawania się mistrzami komunii (por. J 13, 35). Miłość wzajemna i jej

${ }^{25}$ Zob. Konstytucje 1985, nr 5-6; Dyrektorium generalne MSF, Rzym 1985, nr $010-011$.

${ }^{26}$ Zob. Kongregacja do spraw Instytutów Życia Konsekrowanego i Stowarzyszeń Życia Apostolskiego, Instrukcja: Życie braterskie we wspólnocie, Congregavit nos in unum Christi amor (dalej Congregavit) z 04.02.1994, nr 12; Tożsamość i misja, 21.

${ }^{27}$ Constitutiones, 15. 
świadectwo wobec świata stanowią kryterium rozeznania każdej wspólnoty braci, ważniejszym niż skuteczność ich posług ${ }^{28}$.

Brat zakonny znajduje $\mathrm{w}$ swojej rodzinie przestrzeń sprzyjającą rozwojowi jego duchowości. W tych warunkach bracia dzielą ze sobą nawzajem i promują duchowość komunii, która daje życie członkom danej rodziny zakonnej, a od niej - całemu Kościołowi ${ }^{29}$.

Brat zakonny zakorzeniony w Bogu i przesiąkniętym Jego Słowem realizuje swą duchowość w konkretnej działalności apostolskiej. Kontemplacja Boga pomaga widzieć rzeczy i osoby tak, jak widzi je Bóg, a dzięki temu umożliwia odczytywanie znaków czasów. Te z kolei stanowią aktualne dla brata zakonnego wezwanie do działania, aby odkryć obecność Boga w ludziach, szczególnie w ubogich i innych potrzebujących pomocy. Brat przeżywa swoje powołanie wokół ołtarza Słowa, Eucharystii i życia. Jego zadaniem jest troska o zbawienie dusz dla tych, którzy nie mają co jeść i zostali przez świat wykluczeni. To jest eucharystia życia, którą brat powinien celebrować poprzez swoje kapłaństwo chrzcielne, potwierdzone konsekracją zakonną ${ }^{30}$.

Apostolski wymiar duchowości braci zakonnych wypływa z elementów opisanych wyżej. Dokumenty Kościoła i Konstytucje Zgromadzenia MSF, wskazują na pewną prawidłowość, według której: konsekracja i misja są we wspólnocie połączone. Pragnienie duchowości jest widoczne w dzisiejszym społeczeństwie, a bracia zakonni ofiarują samych siebie jako przewodników w poszukiwaniu Boga. Ich gotowość wynika ze zdolności do towarzyszenia ludziom współczesnym na drodze wiary. Jednocześnie przygotowują swoje wspólnoty, aby były szkołami autentycznej duchowości ewangelicznej i oferują je jako „miejsca uprzywilejowane, gdzie doświadcza się dróg, które prowadzą do Boga”. Ich zadaniem jest zatem nawoływanie do modlitwy, poszukiwanie i doświadczenie Boga, ułatwianie lektury Pisma i pogłębianie dialogu między wiarą a kulturą, bycie dla ludzi naszych czasów autentycznymi świadkami nadziei ${ }^{31}$.

\footnotetext{
${ }_{28}$ Zob. Congregavit, 3; VC 64; Tożsamość i misja, 24.

${ }_{29}$ Zob. Tożsamość i misja, nr 38. 7.

${ }^{30}$ Zob. VC 73; Tożsamość i misja, nr 19-20.

${ }^{31}$ Zob. Congregavit, 20; VC 93; Tożsamość i misja, 29.
} 


\section{POSŁANNICTWO}

Duchowość Wcielenia, w którą znakomicie wkomponowuje się duchowość świętorodzinna Zgromadzenia Misjonarzy Świętej Rodziny, za główny swój cel ma tworzenie w świecie jednej wspólnej rodziny dzieci Bożych. Duchowość ta dynamizuje wszelkie charyzmaty braci zakonnych w Zgromadzeniu w postaci konkretnego posłannictwa świadczonego zawsze wspólnie. Stąd pierwszym elementem posłannictwa jest tworzenie wspólnoty. Potwierdzają to dokumenty Kościoła, które podkreślają, że wspólnota pozwala dostrzegać działanie Boga w swoich codziennych zajęciach i odkrywać w nich historię zbawienia. Bracia budują wspólnotę radosnym darem z siebie. Jednoczą się z Chrystusem w Jego ofierze złożonej Ojcu, by kontynuować Jego dzieło zbawcze w swojej wspólnocie ${ }^{32}$.

Analizując temat posłannictwa braci zakonnych dokumenty Kościoła opisują dwie sceny z Ewangelii. Należą do nich: przedstawienie Jezusa, który daje uczniom swoje Ciało i swoją Krew: „[...] to czyńcie na moją pamiątkę" (Łk 22, 19), oraz postawa Jezusa przepasanego prześcieradłem i umywającego uczniom nogi: „Dałem wam bowiem przykład, abyście i wy tak czynili, jak Ja wam uczyniłem” (J 13, 14-15) ${ }^{33}$. W ten sposób nauczanie Kościoła podkreśla, że priorytetowym celem posłannictwa braci zakonnych jest proklamacja i kontynuacja w świecie dzieła zbawczego Chrystusa, czyniona w postawie służebnej. Bracia zakonni pełnią różnorakie i cenne posługi wewnątrz swoich wspólnot i poza nimi, uczestnicząc w ten sposób w misji głoszenia Ewangelii i dawania o niej świadectwa miłości w codziennym życiu. Tak brat ma rozumieć swoją własną służbę, niezależnie od tego, jakie konkretne funkcje zostałyby mu powierzone. Posługa braci rozciąga się również na tych, którzy się oddalili, zagubili, reprezentują inną kulturę ${ }^{34}$.

Ks. Założyciel J. Berthier w Constitutiones (1895) podkreśla znaczenie wspólnoty dla realizacji posłannictwa braci zakonnych w Zgromadzeniu. $Z$ tego względu przywiązuje tak wielką wagę do rekrutacji kandydatów oraz ich podziału. Dzieli braci na koadiutorów i współ-

32 Zob. CHL 32; Tożsamość i misja, 22.

${ }^{33}$ Zob. VC 60; Tożsamość i misja, 12.

${ }^{34}$ Zob. VC 60.72; CHL 21; EG 48-49; Tożsamość i misja, 28.30 
uczestniczących. Kandydaci na braci koadiutorów nadają się do posług materialnych $\mathrm{w}$ domach zakonnych, jak również do funkcji kucharza, ogrodnika, do prac porządkowych, do funkcji furtiana lub katechisty. Kandydaci muszą być sumiennymi, spokojnymi ludźmi, którzy dążą do nabywania cnót i do doskonałości, prowadzą pobożne życie i są zdolni do budowania wspólnoty, zadawalają się rolą Marty, są oddani Instytutowi i pragną być mu pomocni dla większej chwały Bożej. Powinni mieć przyzwoity wygląd, być zdrowi, silni oraz mieć takie uzdolnienia i wiek, by się mogli wykazać w użyteczności dla Instytutu ${ }^{35}$.

Odnośnie przymiotów Constitutiones podkreślają, że Bracia koadiutorzy powinni odznacza się wielką pokorą i oddaniem dla Instytutu, gorliwie wypełniając obowiązki, które im powierzono. Mają oni udział we wszystkich dobrych dziełach, jakich dokonuje Zgromadzenie oraz we wszystkich odpustach udzielonych mu przez Stolicę Świętą. Powinni również być użytecznymi dla bliźnich poprzez duchowe kontakty, dzielić się swoją wiedzą i prowadzić innych ku dobru. Nie powinni także myśleć o zmianie swego statusu, lecz pokornie ćwiczyć się w tym, aby zadania, które zostały im powierzone, dobrze wypełniać, a wszystkie swoje wysiłki kierować ku temu, by robić postępy w wyrzeczeniu i w zakonnych cno$\operatorname{tach}^{36}$. Bracia koadiutorzy mają za swego szczególnego patrona świętego Józefa $^{37}$.

Noszą oni jednolity strój ${ }^{38}$. Założyciel zwraca uwagę na Krucyfiks, który ma im zawsze przypominać, że ich najważniejszym obowiązkiem jest być posłusznym i to z miłości ku Temu, który był posłuszny, aż do

35 Zob. Constitutiones, 49-51. W kwestii przyjmowania kandydaci na braci mają podlegać temu samemu kierownictwu i uczestniczyć w tych samych ćwiczeniach, co pozostali bracia. Zasadniczo nie należy ich przyjmować przed ukończeniem 17 roku życia i nie mogą rozpocząć swojego nowicjatu przed ukończeniem 20 roku życia. Nr. 319.

36 Zob. Constitutiones, 283-285.

37 Bracia nie opuszczają klauzury bez potrzeby i bez pozwolenia. Przed wyjściem i po powrocie proszą swojego przełożonego lub Dyrektora o błogosławieństwo. Constitutiones, 288-299.

38 Podczas codziennej pracy noszą długą koszulę w ciemnym kolorze przepasaną skórzanym pasem, który podtrzymuje krucyfiks, który jest dwa lub trzy centymetry krótszy niż krucyfiks kapłanów. Podobnie jak kapłani, noszą oni ten krucyfiks w sposób widoczny tylko w tych domach zakonnych, w których Przełożony Generalny uzna to za stosowne. Krucyfiks ten otrzymują oni podczas ceremonii 
śmierci na krzyżu ${ }^{39}$. Nad ich formacją czuwa Dyrektor, który w każdym domu jest dla nich wyznaczony i zważa na to, by wiernie odprawiali swoje ćwiczenia duchowne ${ }^{40}$.

Natomiast braci współuczestniczących Założyciel pozwala przyjmować do naszych domów zakonnych jeśli będą zdolni do świadczenia poważnych usług oraz do zachowania reguł, które się do nich odnoszą. O ich przyjęciu decyduje Zarząd Generalny. On też ustala warunki, jakie trzeba im postawić ${ }^{41}$.

W skuteczności misji braci zakonnych pomaga nie tylko wspólnota, ale przede wszystkim sposób przyjęcia przez nich stylu życia Jezusa. Celibat konsekrowany pozwala im żyć pełnią życia wspólnotowego i być braćmi wszystkich. Ten prorocki sposób życia wymaga początkowo zerwania z miejscem pochodzenia, z rodziną, z przyjaciółmi i ze społeczeństwem, aby następnie odzyskać to wszystko, będąc zakorzenionym

przyjęcia do nowicjatu. Koszule i pas otrzymują bracia koadiutorzy przy wstąpieniu do nowicjatu, natomiast pozostałe części stroju otrzymują w dniu swojej profesji. W kościele, w refektarzu, podczas obsługiwania furty i w innych nadzwyczajnych okolicznościach noszą oni swój czarny strój. Mogą również nosić sutannę, gdy muszą pełnić funkcję ministrantów podczas Mszy św., gdy biorą udział w ceremoniach i w ogóle gdy pełnią posługi w kaplicy. Constitutiones, 278-282.286.

${ }^{39}$ Zob. Constitutiones, 286.

${ }^{40}$ Po modlitwie porannej pół godziny adoracji, Msza święta, szczegółowy rachunek sumienia przed południem, po południu Droga krzyżowa połączona z krótkim nawiedzeniem Najświętszego Sakramentu, przynajmniej piętnastominutowe czytanie duchowne. Te trzy ostatnie ćwiczenia powinny być w miarę możliwości odprawiane wspólnie. Wieczorem wspólnotowa modlitwa, rachunek sumienia i przygotowanie rozmyślania na dzień następny; Bracia spowiadają się co osiem dni, na ogół w piątki. W niedziele i jeden raz w tygodniu przystępują do Komunii świętej, a ponadto we wszystkie święta, które zostały wymienione w artykule o scholastykach. Każdego wieczoru lub nazajutrz rano, możliwie jak najwcześniej, udają się do swojego Dyrektora. Constitutiones, 287-292.

${ }^{41}$ Noszą oni ten sam strój, co bracia koadiutorzy, ale krzyż przez nich noszony nie może być dłuższy niż 12 centymetrów. Biorą udział w ćwiczeniach zakonnych danej wspólnoty i w tych, które odprawiają bracia. Chodzi o nabożeństwo drogi krzyżowej, czytanie duchowne, wyznawanie przewinień oraz niedzielne monicje. Jeśli po dwuletnim okresie próby przełożony domowy zechce ich przyjąć na stałe za zgodą Zarządu generalnego, wówczas można ich zapewnić, że w starszym wieku Zgromadzenie zatroszczy się o nich, jeżeli oni w swoim życiu będą się zachowywać jak należy: Constitutiones, 314-318. 
w nowej rodzinie. Bracia zakonni, stawiając czoła teraźniejszości, muszą starać się powtarzać za św. Pawłem: „Co mam czynić, Panie?”. Wierność teraźniejszości wymaga osobistej gotowości na zmianę. Brat ma być kontemplatykiem, aby odkryć Jezusa w ludziach i w wydarzeniach ${ }^{42}$.

Cytowany wyżej dokument Kongregacji ukazuje dwa obrazy ewangeliczne ilustrujące sens misji brata: pierwszy to obraz Jezusa, który karmi obficie chlebem swego Słowa, a ogarnięty współczuciem, prosi swoich uczniów, aby rozdali innym chleb życia doczesnego: „Wy dajcie im jeść!” (Mk 6, 37). Drugi obraz przedstawia Jego współczucie jako autentyczne braterstwo z najbardziej pokrzywdzonymi, aż do utożsamienia się z nimi: „Wszystko, co uczyniliście jednemu z tych braci moich najmniejszych, Mnieście uczynili” (Mt 25, 40. 45). Posłannictwo brata podąża w duchu, którego przedstawiają dwie rozpatrywane wyżej sceny. Stanowi owoc serca, które nie jest obojętne wobec potrzeb i nieszczęść ludzkości. Przynagla, by stać się bratem najmniejszych. W ten sposób, poprzez misję, ofiarowuje dar braterstwa, otrzymany we własnej wspólnocie. Misja brata nie jest „tym co robi”, lecz samym jego życiem, zamienionym w komunię $\mathrm{z}$ najmniejszymi ${ }^{43}$.

Wielu braci zakonnych realizuje swoją misję, wykonując zawody świeckie, w służbie zdrowia lub szkolnictwie, w pomocy socjalnej dla emigrantów, w opiece nad dziećmi i młodzieżą w sytuacjach zagrożenia itp. W ten sposób dają świadectwo, że zaangażowanie na rzecz Królestwa pociąga za sobą także wysiłek budowania świata bardziej ludzkiego oraz że miłość Chrystusa należy połączyć z miłością do ludzi, zwłaszcza do najsłabszych i najbardziej potrzebujących ${ }^{44}$. Wśród posług, jakich wymagają obecne przemiany społeczne i których oczekuje się od braci zakonnych są: gościnność, rozumiana jako otwartość i przyjęcie drugiego człowieka, posługa dialogu i bezinteresownego słuchania, troska o obronę życia i stworzenia ${ }^{45}$.

${ }^{42}$ Zob. VC 39.92-93; Tożsamość i misja, nr 25-26.

${ }^{43}$ Zob. Tożsamość i misja, nr 27.

${ }_{44}$ Zob. tamże, nr 31.

45 Tamże, nr 37. 


\section{FORMACJA BRACI ZAKONNYCH}

W dokumentach Kościoła i Zgromadzenia MSF wiele miejsca poświecono zagadnieniu formacji braci zakonnych. Podzielono ją na początkową i stałą. Formacja początkowa ma na celu pomóc kandydatowi w znalezieniu odpowiedzi na pytania odnośnie jego powołania do takiego rodzaju życia, w określonej rodzinie zakonnej. Ma ułatwić zrozumienie, czy jest gotów będąc bratem, przyjąć postać Sługi, który jest świadom daru, jaki otrzymał od Boga (por. Iz 49, 1. 5). Pomocą w tym zakresie jest zarówno odpowiednia kadra formatorów, jak i właściwe studium eklezjologii komunii i teologii życia konsekrowanego ${ }^{46}$.

Problematykę tę podnosi Dokument Linie odnowy polskiej Prowincji Zgromadzenia, nawiązujący do Dokumentu programowego z 2001 roku. Podtrzymuje zasadę przyjmowania na braci zakonnych młodzieńców, nie wcześniej niż, po ukończeniu szkoły zawodowej lub innej pogimnazjalnej. Podkreśla znaczenie formacji zakonnej, w której bracia mają być wprowadzani w ducha Zgromadzenia i w życie zakonne. Mają otrzymać również formację zawodową i potrzebne wykształcenie ${ }^{47}$.

$\mathrm{Z}$ kolei Dyrektorium prowincjalne zaleca, żeby bracia poznali duchowość i charyzmat Zgromadzenia oraz przyzwyczajać się wypełniać wszystkie obowiązki wynikające ze złożonej profesji. We właściwym rozwoju pomaga im stały spowiednik. Ich duchowa formacja polega, zgodnie z tradycję Zgromadzenia, na szczególnym nabożeństwie do św. Józefa opiekuna Świętej Rodziny i ich patrona ${ }^{48}$. Analizując powołanie młodych braci, należy zwrócić uwagę na to, czy wewnętrznie zaakceptowali takie życie; posiadają ducha wiary i modlitwy i są wierni złożonym ślubom; potrafią łączyć życie apostolskie z życiem wewnętrznym ${ }^{49}$.

Formacja stała braci zmierza do tego, by mogli oni odczytywać na nowo charyzmat założycielski w świetle aktualnych wyzwań i możliwości i inspirować się nim, aby rozwiązywać problemy, jakie niesie teraźniej-

${ }^{46}$ Zob. VC 17.31.69; Tożsamość i misja, nr 34-35; EE 35; MR 29 KPK $659-660$.

47 Zob. Linie odnowy polskiej prowincji Zgromadzenia w latach 2012-2014. Rewizja dokumentu programowego kapituły prowincjalnej 2001, Poznań 2011, s. 16.

${ }_{48}$ Zob. Dyrektorium prowincjalne, 3.24-3.26.

49 Zob. tamże, 3.32. 
szość. Dokument programowy wymienia szereg możliwości kształcenia braci zakonnych w pracy apostolskiej i fizycznej, takich jak: katecheta, organista, ogrodnik, kucharz, stolarz ${ }^{50}$.

Jako pomoc wszechstronnego rozwoju braci zakonnych organizowane są w ramach formacji ciągłej coroczne spotkania braci oraz ich formatorów. Służą one pogłębieniu tożsamości zakonnej braci oraz ich większej integracji, zważywszy na fakt, że mieszkają oni i pracują w różnych domach zakonnych, nierzadko bardzo od siebie oddalonych ${ }^{51}$.

Dyrektorium prowincjalne wiele miejsca poświęca formacji braci zakonnych w junioracie. Podkreśla, że okres ten ma na celu właściwą formację ascetyczno-duchową, intelektualną i praktyczno-zawodową młodych braci zakonnych. W czasie jego trwania zajęcia formacyjne mają bezwzględne pierwszeństwo przed innymi sprawami i zajęciami. W tym okresie braci obowiązują, te same, co innych profesów, praktyki modlitewne i ćwiczenia duchowne. Szczegółowy plan dnia oraz program zajęć ustala dla nich moderator junioratu w porozumieniu z przełożonym domu, w którym znajduję się juniorat. Program ten wymaga zatwierdzenia przez Zarząd prowincjalny ${ }^{52}$.

Obok formacji duchowej w czasie junioratu odbywa się także formacja intelektualna. Bracia pogłębiają swoją wiedzę religijną i otrzymują podstawy wiedzy teologicznej. Przede wszystkim mają zapoznać się z niektórymi dziełami Ojca Założyciela. Ponadto, w ramach cotygodniowych wykładów, zdobywają wiadomości z zakresu: historii Kościoła, teologii życia duchowego, liturgiki, sakramentologii i misjologii ${ }^{53}$.

Ważną sprawą w tym okresie jest właściwa formacja praktyczno-zawodowa i przygotowanie braci do podjęcia przyszłych zadań apostolskich. Formacja praktyczna odbywa się w domu formacyjnym, a wyznaczone prace bracia wykonują pod kierunkiem przełożonego domowego lub ekonoma, w porozumieniu z moderatorem junioratu. Dla lepszej formacji praktycznej piąty rok junioratu brat może spędzić, za zgodą przełożonego prowincjalnego, poza domem formacyjnym ${ }^{54}$.

${ }^{50}$ Zob. Dokument programowy, s. 29.

${ }^{51}$ Zob. Linie odnowy, s. 16-17.

${ }_{52}$ Zob. Dyrektorium prowincjalne, 3.22-3.23

${ }^{53}$ Zob. tamże, 3.27-3.28.

54 Tamże, 3.30-3.31. 
Dokumenty Zgromadzenia podkreślają, że każdy profes o ukończonej formacji zasadniczej musi mieć sposobność i czas na dalszą formację i pogłębianie swojej wiedzy. Bracia zakonni o ukończonej formacji zasadniczej zobowiązani są do udziału w organizowanych dla nich kursach teologicznych. Stroną naukową zajmuje się moderator formacji ciągłej ${ }^{55}$. Ponadto, w pierwszych latach po złożeniu profesji wieczystej, bracia zakonni zobowiązani są do udziału w dwóch miesięcznych kursach organizowanych w Prowincji co trzy lata ${ }^{56}$.

Dyrektorium generalne przypomina, że wyksztalcenie braci zakonnych nie kończy się z zakończeniem nowicjatu. Trwa ono nadal, aż do złożenia ślubów wieczystych. Zarząd prowincjalny mianuje moderatora, odpowiedzialnego za ten czas formacji ${ }^{57}$.

Istotnym elementem formacji braci zakonnych, postulowanym przez Magisterium Kościoła jest stała atencja o rozwój braci starszych. Podkreśla się znaczenie dobrego wcześniejszego przygotowania do zmiany charakteru pracy wraz z upływem lat i sił brata zakonnego. Nie oznacza to jednak zakonnej emerytury. W misji ewangelizacyjnej uczestniczy się zawsze, na różne sposoby. Jeden $\mathrm{z}$ nich, bardzo ważny, to wspieranie wspólnej misji modlitwą i ofiarą; inny - to szereg drobnych posług, jakie można zaoferować stosownie do własnego stanu zdrowia; również świadectwem i przykładem. Współpraca, jakiej oczekuje się od osób starszych, to umiejętność bycia we wspólnocie nauczycielami życia i nadziei, gotowymi towarzyszyć w drodze i trudzie tym, którzy są zaangażowani w zewnętrzne zadania misji. W taki sposób starsi przyczyniają się do tego, by wspólnota służebna była dla całego społeczeństwa prorockim znakiem wiary, miłości i nadziei, którego ono potrzebuje ${ }^{58}$.

55 Tamże, 4.2;4.6.

56 Tamże, 4.8. Program naukowy kursu przygotowuje dyrektor studiów w porozumieniu $\mathrm{z}$ moderatorem junioratu.

57 Zgromadzenie MSF, Dyrektorium generalne MSF, nr 061.

58 Zob. VC 85; Tożsamość i misja, nr 36. 


\section{BIBLIOGRAFIA}

\section{NAUCZANIE KOŚCIOŁA}

Jan Paweł II, Adhortacja apostolska Vita consecrata z 25.03.1996, w: Adhortacje Ojca świętego Jana Pawła II, Kraków 1997, s. 801-946.

Jan Paweł II, Adhortacja apostolska, Christifideles laici z 30.12.1988, w: Adhortacje Ojca świętego Jana Pawła II, Kraków 1997, s. 347-480.

Kongregacja Instytutów Życia konsekrowanego i Stowarzyszeń życia apostolskiego, Tożsamość i misja brata zakonnego w Kościele, Warszawa 2016.

Kongregacja zakonów i instytutów świeckich oraz kongregacja Biskupów, Wytyczne dla wzajemnych stosunków między Biskupami i Zakonnikami w Kościele, Mutue relationes $\mathrm{z}$ 14.05.1978.

Kongregacja zakonów i Instytutów świeckich Essential elements z 31.05.1983, ORpol 7-8 (1983), s. 15-19.

Kodeks Prawa Kanonicznego 1983.

Kongregacja do spraw Instytutów Życia Konsekrowanego i Stowarzyszeń Życia Apostolskiego, Instrukcja: Rozpocząć na nowo od Chrystusa, Poznań 2002.

Kongregacja do spraw Instytutów Życia Konsekrowanego i Stowarzyszeń Życia Apostolskiego, Instrukcja: Życie braterskie we wspólnocie, Congregavit nos in unum Christi amor, z 4.02.1994, http://www.zyciezakonne.pl/dokumenty/kosciol/kongregacjainstytutow-zycia-konsekrowanego-i-stowarzyszen-zycia-apostolskiego/dekretyinstrukcje-wskazania/1994-02-04-instrukcja-zycie-braterskie-we-wspolnocie\%c2\%abcongregavit-nos-in-unum-christi-amor\%c2\%bb-20916/ (data dostępu: 3.04.2018).

Sobór Watykański II, Konstytucje, dekrety, deklaracje, Poznań 1967.

\section{LITERATURA PRZEDMIOTU I POMOCNICZA}

Berthier J., Constitutiones, Reims 1895.

Daniluk M., Encyklopedia Instytutów życia konsekrowanego i Stowarzyszeń życia apostolskiego, Lublin 2000.

Duchniewski J., Bracia, w: Encyklopedia katolicka, t. II, red. F. Gryglewicz i inni, Lublin 1995.

Dokument programowy Polskiej Prowincji MSF, Bąblin 2002.

Dyrektorium polskiej Prowincji MSF, Rzym 1985.

Linie odnowy polskiej prowincji Zgromadzenia w latach 2012-2014. Rewizja dokumentu programowego kapituły prowincjalnej 2001, Poznań 2011.

Zgromadzenie MSF, Dyrektorium generalne MSF, Rzym 1985.

Zgromadzenie MSF, Konstytucje MSF, Rzym 1985. 